ASIMTOT: JURNAL KEPENDIDIKAN MATEMATIKA

Volume 3 Nomor 2, Juni - November 2021, halaman 167 - 176

Tersedia Daring pada https://journal.unwira.ac.id/index.php/ASIMTOT

\title{
ANALISIS KONSEP - KONSEP MATEMATIKA PADA OKO MAMA MASYARAKAT KUANFATU KABUPATEN TIMOR TENGAH SELATAN
}

\section{ANALYSIS OF MATHEMATICAL CONCEPTS IN OKO MAMA KUANFATU COMMUNITY SOUTH CENTRAL TIMOR REGENCY}

Sani Beti, Irmina Veronika Uskono, Meryani Lakapu, Michael Fernandez, Wilfridus Dosinaeng Universitas Katolik Widya Mandira

sanibeti1998@gmail.com, veniuskono@yahoo.com

\begin{abstract}
Abstrak: Penelitian ini merupakan penelitian kualitatif yang bertujuan untuk mendeskripsikan bentuk oko mama masyarakat Kuanfatu kabupaten Timor Tengah Selatan jika ditinjau dari aspek geometri dan konsepkonsep matematika apa saja yang ada pada oko mama masyarakat Kuanfatu kabupaten Timor Tengah Selatan. Penelitian dilakukan di Desa Kuanfatu, Kecamatan Kuanfatu, Kabupaten Timor Tengah Selatan, dengan Objek penelitiannya adalah oko mama masyarakat Kuanfatu dan subjek penelitian adalah pengrajin oko mama. Instrumen dalam penelitian ini menggunakan pedoman observasi dan pedoman wawancara. Hasil penelitian ini menunjukkan bahwa terdapat konsep matematika pada oko mama jika ditinjau dari aspek geometri dan konsepkonsep matematika yang ada pada oko mama. Konsep geometri yang terdapat pada oko mama adalah sudut danbangun datar persegi panjang.
\end{abstract}

Kata Kunci: budaya lokal, oko mama, konsep matematika

Abstract: This research is a qualitative research with the title "Analysis of Mathematical Concepts in Oko Mama, Kuanfatu Community, South Central Timor Regency". This research was conducted because the author sees that there are mathematical concepts in the local culture that exist in the community. Current technological developments make local culture increasingly abandoned by the community, the authors conducted this study aimed to provide an understanding that we can learn mathematics from local culture so that with this local culture is still developed. The research was conducted in Kuanfatu Village, Kuanfatu District, South Central Timor Regency, with the object of the research being Oko Mama, the Kuanfatu community and the subject of the research was the craftsman Oko Mama. The instrument in this study used observation guidelines and interview guidelines. The results of this study indicate that there are mathematical concepts, especially in the field of geometry. The geometric concepts contained in oko mama are angels, flat shapes (rectangels)

Keywords:local culture, oko mama, mahtematical concept

Cara Sitasi: Beti,.S., at.all. (2018). Analisis Konsep-Konsep Matematika Pada Oko Mama Masyarakat Kuanfatu Kabupaten Timor Tengah Selatan . Asimtot: Jurnal Kependidikan Matematika, “3”(“2”), "137-145” 
SSIM!OI',

Pendidikan memiliki peranan penting dalam kehidupan dan kemajuan suatu bangsa. Pendidikan merupakan usaha sadar serta terencana untuk mewujudkan keadaan belajar serta sistem evaluasi untuk peserta didik dengan aktif meningkatkan potensi dirinya untuk memiliki kemampuan spiritual keagamaan, pengendalian diri, kepribadian, kecerdasan, akhlak mulia, dan keterampilan yang dibutuhkan. Pendidikan selalu mengalami perubahan, perkembangan dan perbaikan sesuai dengan perkembangan di segala bidang kehidupan, misalnya pada saat ini pendidikan mengalami banyak perubahan dalam pelaksanaannya karena adanya pandemi covid-19, pendidikan dilaksanakan dari rumah yang mewajibkan peserta didik untuk belajar mandiri hal ini dikarenakan pemerintah berupaya untuk memutuskan mata rantai penyebaran virus corona.

Upaya perubahan dalam pelaksanaan pendidikan saat ini bertujuan untuk menjaga kualitas pendidikan di Indonesia agar tetap baik. Matematika merupakan salah satu pelajaran yang dapat digunakan untuk mengembangkan pengetahuan, kreativitas, dan sikap yang mencakup akhlak, budi pekerti, dan moral serta keterampilan dalam berpikir atau dalam mengerjakan suatu pekerjaan. Matematika merupakan mata pelajaran yang bertujuan secara formal untuk menata nalar seseorang dan secara material untuk mengembangkan pengetahuan serta aplikasinya dalam kehidupan setiap hari. Hal ini berarti matematika berkaitan dengan kehidupan sosial masyarakat setiap hari (Fernandez et al., 2020).

Menurut Rahayu "pemahaman konsep adalah salah satu situasi atau tindakan suatu kelas atau kategori, yang memiliki sifat-sifat umum yang di ketahuinya dalam matematika". Sedangkan menurut Susanto (2013) "pemahaman konsep adalah kemampuan menjelaskan suatu situasi dengan kata- kata yang berbeda dan dapat menginterprestasikan atau menarik kesimpulan dari suatu grapik dan sebagainya". Pemahaman konsep dasar utama adalah pembelajaran matematika. (Vinet \& Zhedanov, 2010) Menurut

Herman menyatakan bahwa "pembelajaran matematika itu membutuhkan pemahaman terhadap konsep-konsep, konsep-konsep ini akan melahirkan teorema atau rumus". Agar konsep-konsep dan teorema-teorema dapat di aplikasikan kesituasi yang lain perlu adanya keterapilan menggunakan konsep- konsep dan teorema-teorema tersebut. Oleh karena itu pembelajaran matematika hasrus di tekankan kearah pemahaman konsep (Vinet \& Zhedanov, 2010).

Pendidikan dan kebudayaan merupakan dua hal yang tidak bisa dipisahkan. Ruang lingkup kebudayaan sangat luas mencakup segala aspek kehidupan manusia. Pendidikan membuat orang semakin berbudaya, makin tinggi kebudayaan makin tinggi pula pendidikan atau cara mendidiknya. Kebudayaan hanya bisa dibentuk oleh pendidikan, itulah sebabnya pendidikan merupakan aspek yang sangat penting dalam kehidupan manusia. Seperti kita ketahui bahwa kebudayaan adalah hasil dari budi daya manusia. Kebudayaan akan selalu berkembang bila budi daya manusia ditingkatkan dalam hal ini melalui bidang 
ASIMTOT: JURNAL KEPENDIDIKAN MATEMATIKA

Volume 3 Nomor 2, Juni - November 2021, halaman 167 - 176

Tersedia Daring pada https://journal.unwira.ac.id/index.php/ASIMTOT

pendidikan. Jadi bila pendidikan maju, maka kebudayaan pun akan semakin maju. Kebudayaan dan pendidikan merupakan dua unsur yang saling mendukung. Budaya lokal adalah merupakan suatu sikap, pola perilaku seseorang yang berhubungan dengan interaksi terhadap alam, masyarakat, dan lingkungan sekitarnya.

Budaya lokal berkembang dengan menyesuaikan dari nilai-nilai, agama, adatistiadat dan falsafah leluhur yang diturunkan kepada generasi penerus baik melalui tradisi lisan maupun tulisan. Bahwa budaya lokal dapat mengintegrasikan nilai atau unsur dalam budaya yang berkaitan dengan matematika yang bertujuan untuk memahami konsep matematika pada aspek budaya yang digunakan untuk menyelesaikan permasalahan sehari-hari ke dalam bentuk matematika. Menurut Wahyuni (2013), ketika suatu materi begitu jauh dari skema budaya yang mereka miliki tentunya materi tersebut sulit untuk dipahami.

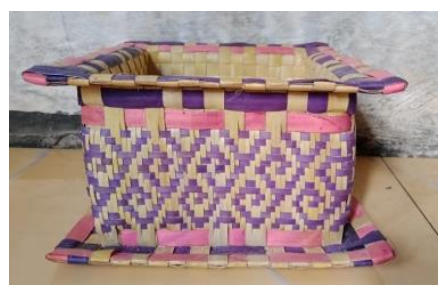

Gambar 1.1 Oko Mama

(sumber : Dokumen Pribadi)

Tradisi oko mama berlangsung terus menerus dan dijadikan titik tolak perkembangan masyarakat dari masa ke masa. Tradisi oko mama tidak hanya dipandang sebagai pengetahuan semata melainkan turut direalisasikan dalam perwujudan sikap hidup sehari-hari. Tradisi oko mama memiliki sebuah sistem nilai yang menyeluruh menyangkut hubungan manusia dengan kekuasaan yang melingkupinya (transenden), hubungan manusia dengan manusia serta hubungan manusia dengan alam sekitar (Makleat, 2020).

Oko mama terbuat dari anyaman daun lontar yang terdiri atas oko mama enan (yang besar atau kotaknya) dan bagian Toben (tutupannya). Oko mama yang sering digunakan oleh masyarakat Timor Tengah Selatan adalah oko mama yang bentuk menyerupai bangun ruang kubus, dengan permukaannya menyerupai bangun datar persegi.

\section{Metode Penelitian}

Penelitian ini termasuk dalam jenis penelitian kualitatif. Penelitian kualitatif adalah penelitian yang menghasilkan data deskriptif berupa kata-kata tertulis atau lisan dari orang-orang atau perilaku yang diamati. Objek penelitian adalah oko mama masyarakat kuanfatu, Subjek penelitian adalah pengrajin oko mama Masyarakat Kuanfatu, Pemilihan subjek ini dengan cara mencari tahu dari masyarakat setempat dan melakukan pendekatan sebelumnya dan dilakukan secara acak. Penelitian ini dilaksanakan di Oetbolan RT 01/ RW 01, Dusun 01, Desa Kuanfatu, Kecamatan Kuanfatu, Kabupaten Timor Tengah Selatan (TTS), Propinsi Nusa Tenggara Timur (NTT). Pengumpulan data dilakukan untuk memperoleh data-data yang relevan dan 
ASIMTOT: JURNAL KEPENDIDIKAN MATEMATIKA

Volume 3 Nomor 2, Juni - November 2021, halaman 167 - 176

Tersedia Daring pada https://journal.unwira.ac.id/index.php/ASIMTOT

akurat. Dalam penelitian ini, teknik pengumpulan data yang digunakan yaitu observasi, dokumentasi dan wawancara. Instrument penelitian yang digunakan adalah peneliti, pedoman observasi, pedoman wawancara, dan dokumentasi. Untuk mencapai tujuan dalam penelitian ini, maka langkah-langkah yang digunakan adalah pendahuluan, pengamatan, persiapan, pemilihan subjek penelitian, pengumpulan data, analisis data dan penarikan kesimpulan. Teknik analisis data dalam penelitian ini dianalisis yaitu tahap reduksi data, penyajian data dan penarikan kesimpulan.

\section{Hasil Penelitian dan Pembahasan}

Objek dari penelitian ini adalah oko mama masyarakat desa Kuanfatu. oko mama adalah adalah satu kerajinan tangan dan juga sebagai sumber pendapatan bagi masyarakat setempat, kerajinan oko mama terbuat dari hasil bumi berupa daun lontar, oko mama digunakan sebagai wadah untuk menyuguhkan sirih pinang bagi tamu. Saat ini, seiring dengan perkembangan zaman banyak kreatifitas dari masyarakat setempat yang membuat oko mama dari bahan daur ulang seperti dari bahan plastik bekas minuman, gardus dan lain-lain, tetapi oko mama yang terbuat dari daun lontar yang diteliti oleh peneliti, oko mama yang dijaga turun temurun oleh masyarakat setempat karena memiliki makna dan nilai tersendiri.

Oko mama masyarakat Kuanfatu ada beberapa jenis yaitu oko mama oko mama yang digunakan untuk ritual adat dan oko mama yang selalu digunakan setiap hari sebagai wadah untuk memberikan sirih pinang bagi tamu. Berikut ini gambar perbedaan antara oko mama untuk adat dan oko mama yang digunakan setiap hari;

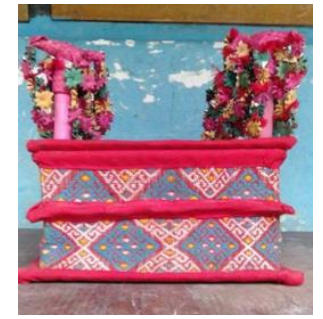

Gambar 4.2 Oko Mama untuk Acara Adat (Sumber : Dokumen Pribadi)

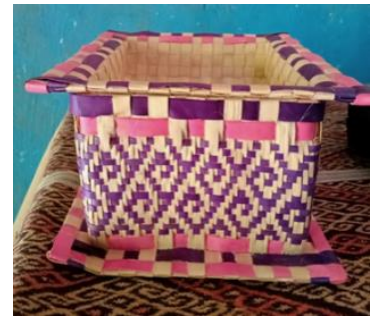

Gambar 4.3 Oko Mama yang digunakan setiap hari (Sumber : Dokumen Pribadi)
Gambar 4.3 merupakan oko mama yang digunakan pada saat acara adat seperti peminangan, pernikahan adat, dan penyambutan tamu tertent ( pemerintah dan tua adat). Pada saat upacara adat oko mama diisi dengan sirih pinang, uang, kain tenunan masyarakat setempat, dan barang-barang misalnya hantaran saat peminangan. Oko mama adat ini memiliki ciri khas yaitu ada banyak pernak-pernik yang ditambahkan.

Gambar 4.4 merupakan oko mama yang digunakan setiap hari oleh masyarakat setempat sebagai wadah untuk memberikan sirih pinang. Oko mama ini dianyam dengan sederhana tanpa menambahkan aksesoris, yang bertujuan agar jangan mudah rusak dan otor. Oko mama yang digunakan setiap hari berisikan sirih pinang sebagai tradisi masyarakat setempat untuk menyambut tamunya saat berkunjung sebelum disuguhkan minum atau makan, tradisi ini sangat dijaga dan dilestarikan oleh masyarakat. Bila tamu diberikan sirih pinang tamu harus 
ASIMTOT: JURNAL KEPENDIDIKAN MATEMATIKA

Volume 3 Nomor 2, Juni - November 2021, halaman 167 - 176

Tersedia Daring pada https://journal.unwira.ac.id/index.php/ASIMTOT

mengambilnya karena hal ini adalah suatu kehormatan bagi tuan rumah, sehingga walaupun tamu tidak biasa dengan memamah sirih pinang tetapi untuk menghargai tuan rumah maka tamu wajib mengambilnya walaupun tidak akan memamah. Oko mama yang diteliti oleh peneliti adalah oko mama yang digunakan setiap hari sebagai wadah untuk memberikan sirih pinang.

Aktivitas Matematis dalam Pembuatan Oko Mama. Dari data yang diperoleh, peneliti menemukan adanya aktivitas matematis dalam proses pembuatan oko mama, yakni:

a. Aktivitas Mengukur

Aktivitas mengukur ini dilakukan oleh pengrajin dalam mempersiapkan bahanbahan oko mama. Alat ukur yang digunakan adalah alat ukur tradisional yang berasal dari daun lontar yaitu lidinya sendiri yang biasa disebut dengan Hepa. Hepa adalah alat ukur untuk membagi daun lontar yang ukurannya tidak menentu, hepa digunakan untuk mengukur lebar dari daun lontar yang ukurannya berkisar antara $1-1,5 \mathrm{~cm}$.

b. Aktivitas Menghitung

Aktivitas menghitung ini dilakukan pengrajin pada saat mempersiapkan bahan daun lontar yang dibutuhkan. Persiapan daun lontar akan disesuaikan dengan oko mama yang akan dianyam dan oko mama tersebut membutuhkan berapa banyak pucuk daun lontar.

Oko mama terdiri atas oko mama enan yang merupakan bagian yang menampung sirih pinang dan bagian oko mama yang talan selain sebagai penutup juga sebagai wadah saat memberikan sirih pinang.

\section{a. Bagian alas dari oko mama}

Alas dari oko mama, saat proses anyaman akan dianyam terdahulu sebagai dasar dari oko mama. Setelah melakukan observasi, peneliti pun mendapati bentuk matematika khususnya bagian geometri (bangun datar) pada bagian alasnya. Bentuk geometri pada oko mama ini, yakni:

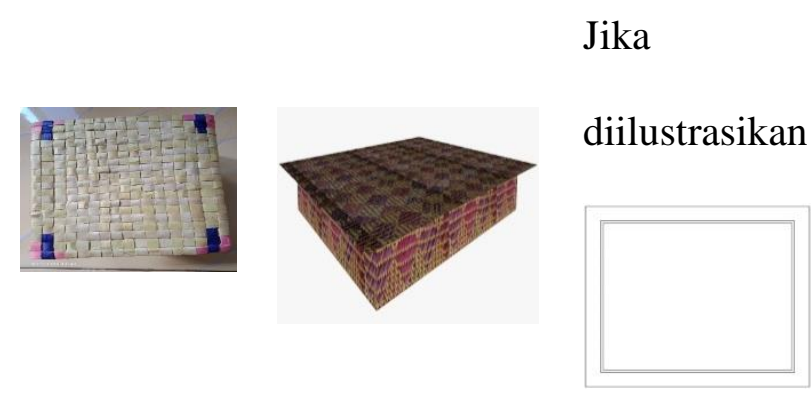

b. Bagian dinding dari oko mama

Oko mama memiliki dinding, dan pada dinding ini terdapat juga ukiran motif-motif sebagai ciri khas dari masyarakat setempat, dan setiap motif memiliki maknanya tersendiri. Dinding Oko mama terdiri dari empat bagian, dari dinding ini sebagai penopang tutupan oko mama atau biasa disebut dengan toben, motif dari oko mama ini biasanya berwarna dikarenakan daun lontar di masak dengan pewarna untuk memperindah oko mama tersebut. Dari hasil observasi dan wawancara peneliti menemukan beberapa nilai matematis yaitu bentuk geometri yang terdapat pada dinding oko mama. Berikut tampak dari dinding oko mama, beserta bentuknya: 
ASIMTOT: JURNAL KEPENDIDIKAN MATEMATIKA

Volume 3 Nomor 2, Juni - November 2021, halaman 167 - 176

Tersedia Daring pada https://journal.unwira.ac.id/index.php/ASIMTOT

\section{c. Bagian Tutup ( Talan )}

Setelah alas dan dinding dari oko mama dianyam, selanjutnya adalah tutupan dari oko mama. Untuk tutupan oko mama karena agak melengkung ke dalam pada saat anyaman juga membutuhkan waktu yang cukup lama, lengkungan pada tutupan oko mama bertujuan agar pada saat menyimpan sirih pinang tidak terjatuh. Setelah membuat tutupannya langkah selanjutnya adalah membuat motif.

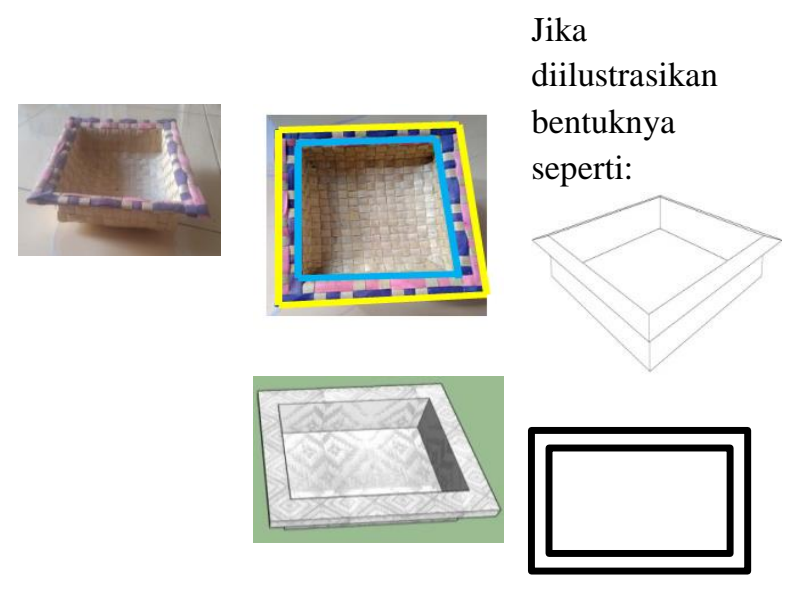

Budaya lokal ada unsur matematika yang bersifat nyata dapat dilihat pada oko mama. Oko mama ini mengandung nilai-nilai matematis khususnya geometri yang diterapkan secara tidak sengaja oleh masyarakat dalam menganyam. Oko mama ini memiliki tiga bagian, yaitu alas, dinding, dan tutupan. Setiap bagian dari oko mama ini akan dijelaskan dengan kajian matematis sesuai dengan aktivitas yang ditemukan di masyarakat kuanfatu. Berdasarkan hasil penelitian yang sudah dipaparkan sebelumnya, terdapat aktivitas matematis
Jika

diilustasikan
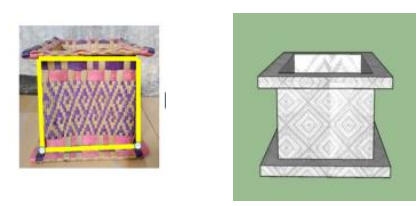

bentuknya

seperti:

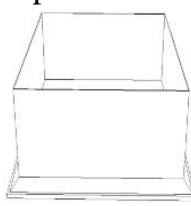

dalam proses anyaman oko mama. Bishop menyatakan bahwa budaya lokal dapat dibagi menjadi enam kegiatan mendasar yang selalu dapat ditemukan pada sejumlah kelompok budaya. Keenam kegiatan matematika tersebut adalah aktivitas: menghitung/membilang, penentuan lokasi, mengukur, mendesain, bermain dan menjelaskan (Hardiarti, 2017) . Objek matematis dapat berupa bangunan-bangunan, kerajinan tradisional, permainan tradisional, dan tindakan yang berbudaya. Dalam penelitian ini peneliti menemukan adanya aktivitas matematis yang dilakukan masyarakat kuanfatu, serta hal yang menyangkut geometri dalam menganyam oko mama yakni;

a. Mengukur pada dasarnya membutuhkan alat ukur yang baku sesuai dengan standar internasional yang berlaku di seluruh dunia. Pengukuran merupakan penentuan besaran, dimensi, atau kapasitas, biasanya terhadap suatu standar atau satuan pengukuran (Hartoyo, 2012). Aktivitas mengukur merupakan salah satu aktivitas matematis yang dilakukan oleh masyarakat Kuanfatu pada saat proses menganyam oko mama. Hal mengenai ukuran, itu semua sudah dipahami oleh pengrajin sendiri dan kemampuan dalam 
ASIMTOT: JURNAL KEPENDIDIKAN MATEMATIKA

Volume 3 Nomor 2, Juni - November 2021, halaman 167 - 176

Tersedia Daring pada https://journal.unwira.ac.id/index.php/ASIMTOT

mengukur pengrajin memiliki alat ukur yang biasa disebut Hepa dan alat ukur tersebut ukurannya tidak menentu karena pada saat mengukur pengrajin lebih mengutamakan naluri. Hepa hanya sebagai alat bantu dalam mengukur yang tidak memiliki satuan tertentu, naluri dari pengrajin yang sangat kuat dari turuntemurun yang tidak bisa dimiliki oleh banyak orang, hal ini yang membuat pengrajin istimewa karena memiliki naluri matematis yang tinggi. Masyarakat dahulu pada dasarnya tidak mengunakan satuan yang baku dalam menganyam Oko mama. Hal ini dikarenakan dulu konsep matematika yang sudah berkembang seperti sekarang ini belum dikenal oleh masyarakat. Walaupun dulu masyarakat menggunakan ukuran yang tidak baku, namun masyarakat secara tidak sengaja sudah menerapkan aktivitas mengukur pada anyaman oko mama dengan baik dan menghasilkan bentuk yang simetris. Dari hasil wawancara peneliti mendapatkan bahwa satu Hepa sama dengan $1 \mathrm{~cm}$ - 1,5 $\mathrm{cm}$.

b. Sudut dapat didefinisikan sebagai bangun geometri yang dibentuk oleh dua sinar dengan titik pangkal yang berimpit dan titik pangkal tersebut disebut dengan sudut (Tohir, 2017). Ada beberapa Sudut yang terdapat di oko mama yakni sudut pada alas, sudut pada dinding, dan sudut pada tutupan. Berikut gambar tentang sudut yang terdapat di oko mama. Dari hasil data diatas peneliti menemukan bahwa sudut - sudut yang ada pada alas, dinding, dan tutupan oko mama sama yaitu sudut siku-siku dengan besar sudutnya adalah $90^{\circ}$.

Menghitung adalah suatu perbuatan untuk menentukan nilai atau solusi sesuatu hal melalui proses matematika (menjumlahkan, mengurangi, mengalikan, membagi, dsb) (Nurmasari, 2011)

Aktivitas menghitung ditemukan dalam masyarakat Kuanfatu pada proses menganyam Oko Mama. Hitungan yang diterapkan dalam pembuatan oko mama mengenai berapa banyak daun lontar yang dibutuhkan oleh pengrajin, lebar daun dan pada saat proses penganyaman menggunakan hitungan pepa mese atau satu-satu dan dibutuhkan banyaknya daun lontar untuk menghasilkan oko mama ukuran tertentu. Dalam penelitian ini peneliti mencari tahu nilai matematis pada satu oko mama.

Ada cara-cara berbeda dalam mencari tahu nilai matematika dengan mempertimbangkan pengetahuan matematika akademik yang dikembangkan oleh berbagai sektor masyarakat serta dengan mempertimbangkan modus yang berbeda di mana budaya yang berbeda merundingkan praktek matematika mereka (cara mengelompokkan, berhitung, mengukur, merancang bangunan atau alat, bermain dan lainnya) atau bisa dikatakan bahwa aktivitas mendesain/merancang berhubungan dengan semua benda-benda yang dihasilkan budaya untuk keperluan (Nuh \& Dardiri, 2016).

Dalam hal ini bahan-bahan yang digunakan untuk membuat oko mama, aktivitas menghitung dan mengukur dapat dilihat/ditemukan pada perencanaan/desain dan pelaksanaan penganyaman oko mama. 
ASIMTOT: JURNAL KEPENDIDIKAN MATEMATIKA

Volume 3 Nomor 2, Juni - November 2021, halaman 167 - 176

Tersedia Daring pada https://journal.unwira.ac.id/index.php/ASIMTOT

Pada perencanaan pengrajin sudah mengetahui apa yang harus dilakukan terlebih dahulu dan seterusnya dengan melakukan hitungan dan pengukuran yang sudah diketahui terlebih dahulu dan pola pada proses anyaman adalah pola berulang.

\section{Simpulan dan Saran}

\section{Simpulan}

Berdasarkan hasil kajian terhadap oko mama, maka dapat diperoleh hal-hal sebagai berikut:

1. Terdapat aktivitas matematis dalam masyarakat Kuanfatu saat proses menganyam oko mama. Aktivitas yang terdapat di masyarakat yaitu aktivitas megukur, mengitung. Saat mengukur, masyarakat menggunakan alat ukut yang tidak baku. Istilah dari alat ukur tersebut yaitu 'hepa'. Kemudian untuk menghitung, masyarakat pun sudah melakukan aktivitas menghitung saat mempersiapkan bahan dan memperkirakan pengeringan daun lontar serta pada saat menganyam. Aktivitas menghitung dan mengukur ini dapat ditemukan pada proses penganyaman atau perencanaan/desain oko mama.

2. Konsep Matematis yang Terdapat di oko mama saat peneliti melakukan penelitian yaitu konsep matematis yang berkaitan dengan geometri, yakni sudut, dan bangun datar ( persegi panjang). Berikut penjelasannya :

a. Terdapat sudut siku-siku di beberapa bagian oko mama yaitu sudut siku- siku yang ada di tutupan, dinding, dan alas. Materi mengenai sudut dipelajari di kelas VII pada materi garis dan sudut.

b. Bangun datar yang terdapat pada oko mama yaitu Persegi Panjang. Persegi panjang dapat dilihat dari bentuk tutupan, dinding, dan alas dari oko mama. Persegi panjang ada pada materi segiempat dan segitiga di kelas VII.

\section{Saran}

Berdasarkan kesimpulan yang diperoleh peneliti yaitu mengeksplorasi aktivitas nilai matematis yang tumbuh dan berkembang dalam kebudayaan (oko mama) masyarakat Kuanfatu, maka hal-hal yang perlu peneliti sampaikan sebagai berikut :

1. Pengumpulan data dan menemukan nilai matematis pada oko mama dilakukan sendiri oleh peneliti namun peneliti belum menerapkan langsung di sekolah. Kiranya ada tindak lanjut dari penelitian ini untuk menerapkannya di sekolah.

2. Penelitian ini hanya untuk menemukan nilai matematis yang terdapat di oko mama dan sebagai sumber belajar secara umum yang tidak memperhatikan jenjang tingkatan sekolah.

3. Untuk meningkatkan pembelajaran yang saat ini lebih menekankan pada aspek kebudayaan, ada baiknya dibuatkan modul yang dikaitkan dengan nilai matematika agar peserta lebih mengenal dan mencintai budayanya dan juga mencintai matematika. 


\section{ASIMTOT: JURNAL KEPENDIDIKAN MATEMATIKA}

\section{Volume 3 Nomor 2, Juni - November 2021, halaman 167 - 176}

Tersedia Daring pada https://journal.unwira.ac.id/index.php/ASIMTOT

\section{Daftar Pustaka}

Aprilia, Dwi, E. (2019). Etnomatematika pada Permainan Tradisional Engklek Beserta Alatnya Sebagai Bahan Ajar. Articel, 10(1), 85-94.

Etanol, E., Waru, D., \& Hibiscus, G. (2017). Digital Digital Repository Repository Universitas Universitas Jember Jember Bacillus cereus Digital Digital Repository Repository Universitas Universitas Jember.

Fatkhan Amirul Huda. (2019). Pengertian Konsep Matematika. 26 September. https://fatkhan.web.id/pengertiankonsep-matematika/

Fernandez, M., Djong, K. D., Dosinaeng, W. B. N., Fernandez, A. J., Lakapu, M., Matematika, P., Katolik, U., \& Mandira, W. (2020). Pembelajaran Geometri Bidang dan Ruang Berbasis Etnis Timor. Pengabdian Masyarakat, 03(02), 68-76. https://jurnal.unimor.ac.id/BC/article/vie w/616

Hardiarti, S. (2017). Etnomatematika: Aplikasi Bangun Datar Segiempat Pada Candi Muaro Jambi. Aksioma, 8(2), 99. https://doi.org/10.26877/aks.v8i2.1707

Hartoyo, A. (2012). Eksplorasi Etnomatematika pada Budaya Masyarakat Dayak Perbatasan IndonesiaMalaysia Kabupaten Sanggau Kalbar. Jurnal Penelitian Pendidikan, 13(1), 1423. http://jurnal.upi.edu/penelitianpendidikan/view/1387/eksplorasietnomatematika-pada-budayamasyarakat-dayak-perbatasan-indonesiamalaysia-kabupaten-sanggau-kalbar.html

Makleat, N. (2020). Tradisi Okomama sebagai Media Penyelesaian Masalah Kekerasan Dalam Rumah Tangga (KDRT) di Kecamatan Kota Soe, Nusa Tenggara Timur. 2(2), 53-56. https://www.google.com/searchq Tradisi Okomama Kota Soe Nusa Tenggara Timur

Nuh, Z. M., \& Dardiri. (2016). Etnomatematika Dalam Sistem Pembilangan Pada Masyarakat Melayu Riau. Kutubkhanah, 19(2), 220-238. http://ejournal.uin-

suska.ac.id/index.php/Kutubkhanah/artic le/view/2552

Nurmasari, L. (2011). Melalui Metode Jarimatika Pada Siswa Kelas Ii Sd Negeri 3 Pringanom Sragen Pada Siswa Kelas Ii Sd Negeri 3 Pringanom Sragen.

Rahmah, N. (2018). Hakikat Pendidikan Matematika. Al-Khwarizmi: Jurnal Pendidikan Matematika Dan Ilmu Pengetahuan Alam, 1(2), 1-10. https://doi.org/10.24256/jpmipa.v1i2.88

Riyanto, A. (2013). Pengertian Analisis. Journal of Chemical Information and Modeling, 53(9), 1689-1699. http://repository.uinsuska.ac.id/4184/3/BAB II.pdf

Savira, F., \& Suharsono, Y. (2013). Degradasi Fungsi, Makna dan Nilai Budaya Oko Mama pada Komunitas Tutur Uab Meto. Journal of Chemical Information and Modeling, 01(01), 1689-1699.

Shidiq, U., \& Choiri, M. (2019). Metode Penelitian Kualitatif di Bidang Pendidikan. In A. Mujahidin (Ed.), Journal of Chemical Information and Modeling (Vol. 53, Issue 9). CV.Nata Karya.

http://repository.iainponorogo.ac.id/484/ 1/Metode Penelitian Kualitatif di Bidang Pendidikan.pdf

Sumarmo. (2019). Pengertian Matematika. Pengertian Matematika, Ju;i, 1-26.

Tohir, M. (2017). Penguatan Konsep Garis dan Sudut. Moda Daring, 1, 100.

Vinet, L., \& Zhedanov, A. (2010). A 
ASIMTOT: JURNAL KEPENDIDIKAN MATEMATIKA

Volume 3 Nomor 2, Juni - November 2021, halaman 167 - 176

Tersedia Daring pada https://journal.unwira.ac.id/index.php/ASIMTOT

"missing" family of classical orthogonal polynomials. Journal of Chemical Information and Modeling, 53(9), 16891699. https://doi.org/10.1088/17518113/44/8/085201. 